\title{
Effect of Some Organic, Inorganic and Biofertilization Treatments on Fruiting of Early Sweet Grapevines
}

${ }^{*}$ Ahmed, F. F. ${ }^{1}$; M. A.M. Abada ${ }^{2}$; M. Kh. Uwakiem ${ }^{2}$ and B.E.A. Belal ${ }^{2}$

${ }^{1}$ Hort. Dept. Fac. of Agric. Minia Univ., Egypt

${ }^{2}$ Viticulture Res. Dept. Hort. Res. Inst. ARC. Giza, Egypt

"Email: Faissalfadel@yahoo.com

Received on: 21/9/2016

Accepted for publication on: 28/9/2016

Abstract

During 2013, 2014 and 2015 seasons, Early sweet grapevines received $\mathrm{N}$ as $100 \%$ mineral $\mathrm{N}$ or as $25 \%$ to $75 \%$ mineral $\mathrm{N}$ with 12.5 to $37.5 \%$ plant compost and Minia Azotene biofertilizer. The target was selecting the best ratio between different $\mathrm{N}$ sources.

Using $\mathrm{N}$ as 50 to $75 \%$ mineral $\mathrm{N}$ besides 12.5 to $25 \%$ plant compost and Minia Azotene biofertilizer gave the best results with regard to growth and yield. An obvious reduction on yield was observed with using $\mathrm{N}$ as $25 \%$ mineral $\mathrm{N}+$ $37.5 \%$ plant compost $+37.5 \%$ Minia Azotene biofertilizer.

For improving yield of Early sweet grapevines, it is suggested to use $\mathrm{N}$ as $50 \%$ mineral $\mathrm{N}$ plus $25 \%$ plant compost and 25\% Minia Azotene, for promoting physical and chemical characteristics of the berries, it is recommended to use $\mathrm{N}$ as $25 \%$ mineral $\mathrm{N}+37.5 \%$ plant compost $+37.5 \%$ Minia Azotene biofertilizer.

Keywords: Inorganic, organic and biofertilization nitrogen, Early sweet grapevines, yield, berries quality.

\section{Introduction}

Early sweet grapevine cv. is considered a prime and outstanding grapevine cv. grown under Egypt conditions. It ripens early especially when treated with breakages and easily marketing to most foreign countries. Reducing pollution in such grapevines cv. during production is accompanied with facilitating marketing of such grapevine cv. Reducing mineral $\mathrm{N}$ fertilization and at the same time increasing organic and biofertilizations is considered a backbone of enhancing exportation process.

Organic and biofertilization are essential for enhancing soil fertility and increasing the availability of most nutrients to the vine. Accumulation of toxic $\mathrm{N}$ compounds was low- ered at the higher extent with using these stimulators. (Mengel, 1984).

Madian (2010) suggested that using all sources of $N$ was favourable in enhancing yield and berries quality of Red Roomy grapevines relative to using mineral $\mathrm{N}$ alone.

Refaai (2011) supported the beneficial effects of using $\mathrm{N}$ in all sources at suitable proportions on improving yield and quality of Thompson seedless grapes.

The results of Uwakiem (2011); Mekawy (2012); El- Khafagy (2013); Shaaban (2014); Alam (2014); Abd El- Kareem(2014) and Abd El- Razek (2014) confirmed the essential of using $\mathrm{N}$ via inorganic and bioforms at balanced rate on yield and fruit quality of various grapevine cvs. 
The target of this study was examining the effect of using plant compost and Minia Azotene biofertilizer as a partial replacement of mineral $\mathrm{N}$ fertilizer in Early sweet grapevine vineyards.

\section{Materials and Methods}

This study was carried out during 2013 \& 2014 and 2015 seasons on thirty - six nearly uniform in vigour 8- years old early sweet grapevines grown in a private vineyards located at west Matay, Matay district,
Minia Governorate where the texture of the soil is sandy Table (1) well clrained the selected vines are planted at $1.5 \times 3.0 \mathrm{~m}$ apart. Winter pruning was done on 1st, 3rd and 5th Jan. during the three seasons using short pruning system. The vines were trellises by Gable system. Vine load was 78 eyes (22 fruiting spurs x 3 eyes + six replacement spurs $\mathrm{x}$ two eyes). Drip irrigation system was followed Table (1) shows the results of soil analysis (Black et al., 1965).

Table 1. Analysis of the tested soil

\begin{tabular}{|c|c|}
\hline Constituents & Values \\
\hline Particle size distribution & \\
\hline Sand \% & 71.9 \\
\hline Silt \% & 18.0 \\
\hline Clay \% & 10.1 \\
\hline Texture & Sandy \\
\hline pH ( 1: 2.5 extract) & 7.66 \\
\hline O.M. \% & 0.24 \\
\hline CaCO3 \% & 1.94 \\
\hline Total N \% & 0.04 \\
\hline Available P ( Olsen method) ppm & 1.1 \\
\hline Available K (ammonium acetate) ppm & 22.2 \\
\hline EDTA extractable micronutrients (ppm) & \\
\hline Fe & 0.9 \\
\hline Zn & 0.7 \\
\hline Mn & 2.2 \\
\hline Cu & 0.71 \\
\hline
\end{tabular}

This study included the following four treatments:

Application of the recommended N (60 g N/ vine / year) via 100\% mineral N (179 g ammonium nitrate $33.5 \% \mathrm{~N} /$ vine / year).

Application of $75 \%$ of the recommended $\mathrm{N}$ via mineral $\mathrm{N}$ ( $134.3 \mathrm{~g}$ ammonium nitrate / vine / year $)+12.5 \%$ plant compost $2 \% \mathrm{~N}$ ( $375 \mathrm{~g}$ plant compost / vine / year $)+$ $12.5 \%$ Minia Azotene $(7.5 \mathrm{ml} /$ vine / year).

Application of $50 \%$ of the recommended $\mathrm{N}$ via mineral $\mathrm{N}(89.5 \mathrm{~g}$ ammonium nitrate / vine / year) $+25 \%$ plant compost (750 g plant compost / vine / year) $+25 \%$ Minia Azotene (15 ml/ vine / year).

Application of $25 \%$ of the recommended $\mathrm{N}$ via mineral $\mathrm{N}$ (44.8 g ammonium nitrate / vine / year $)+37.5 \%$ plant compost (1125 g plant compost / vine / year $)+37.5 \%$ Minia Azotene (22.5 ml/ vine / year). 
Each treatment was replicated three times, three vines per each. All the tested vines received $\mathrm{N}$ at fixed rate namely $60 \mathrm{~g} / \mathrm{vine} / \mathrm{year}$. Mineral $\mathrm{N}$ in the form of ammonium nitrate $(33.5 \% \mathrm{~N})$ was splitted into three unequal batches added as $40 \%$ at growth start, $30 \%$ just after berry setting and at 30\% 30 days later. It was broadcast around each vine under canopy and $40 \mathrm{~cm}$ for farm trunk. Plant compost was added once at the last week of January in the shallow trenches $(10 \mathrm{~cm}$ length $\mathrm{x} 10 \mathrm{~cm}$ depth $\mathrm{x} 10 \mathrm{~cm}$ width) around each vine under vine canopy. Minia Azotene biofertilizer (each ml contains $0.6 \times 10^{8}$ bacterial cell) was added once at growth start (Mid. of March) and it was applied in shallow trenches (10x $10 \times 10 \mathrm{~cm}$ ) and covered with most soil. Randomized complete block design (RCBD) was followed where the study included four treatments, each treatment was replicated three times, three vines per each.

Table 2. Analysis of plant compost

\begin{tabular}{|c|c|}
\hline Constituents & Values \\
\hline pH ( 1 : 2.5 extract & 8.5 \\
\hline O.M. \% & 31.0 \\
\hline Total N \% & 2.0 \\
\hline Total P \% & 0.52 \\
\hline Total K \% & 1.12 \\
\hline Total Fe (ppm) & 320.0 \\
\hline Total Mn (ppm) & 45.0 \\
\hline Total Cu (ppm) & 42.0 \\
\hline Total Zn (ppm) & 34.0 \\
\hline
\end{tabular}

During the three seasons, the following measurements were recorded

Main shoot length $(\mathrm{cm})$.

Number of leaves/ shoot.

Leaf area (cm2) (Ahmed and Morsy, 1999).

Wood ripening coefficient ( Bouard, 1966).

Cane thickness $(\mathrm{cm}$.

Wood pruning weight $\mathrm{kg} /$ vine.

Leaf pigments namely chlorophylls a, b, total chlorophylls and total carotenoids (mg/ 100 g F.W.) (Von- Wettstein, 1957).

Percentages of N, P, K and Mg (Summer, 1985, Chapman and Pratt, 1987 and Balo et al., 1988).

Berry setting \%.

Yield expressed in number of clusters per vine and weight (kg.) vine.

Cluster weight.

Berry weight (g.) and dimension (longitudinal and equatorial, in $\mathrm{cm}$ )

Shot berries \%.

Chemical characteristics of the berries namely T.S.S., total sugars and total acidity (A.O.A.C., 2000) as a tartaric acid / $100 \mathrm{ml}$ juice, nitrate and nitrite in the juice (Rindnour - Lisa et al., 2000).

Total counts of bacteria (Cochran, 1950). (cfu/ $1 \mathrm{~g}$ soil).

Statistical analysis was done according to Mead et al., (1993). Treatment means were compared using new L.S.D. 5\%. 


\section{Results and Discussion teristics: \\ 1- Vegetative growth charac-}

It is clear from the data in Table

(3) that supplying Early sweet grapevines with $\mathrm{N}$ as 50 to $75 \%$ mineral $\mathrm{N}$ besides 12.5 to $25 \%$ plant compost and Minia Azotene biofertilizer significantly stimulated main shoot length, number of leaves/ shoot, leaf area, wood ripening coefficient, cane thickness and wood pruning weight comparing with using $\mathrm{N}$ as $100 \%$ mineral $\mathrm{N}$ or when mineral $\mathrm{N}$ was added at $25 \%$ with $37.5 \%$ plant compost or Minia Azotene. Using $\mathrm{N}$ as $25 \%$ mineral $\mathrm{N}$ besides $37.5 \%$ plant compost and Minia Azotene significantly reduced these growth characteristics. Using $\mathrm{N}$ as $100 \%$ mineral $\mathrm{N}$ significantly enhanced these growth aspects, over the application of $\mathrm{N}$ as $25 \%$ mineral $\mathrm{N}$ plus $37.5 \%$ plant compost or Minia Azotene. The maximum values were recorded on the vines that fertilized with $\mathrm{N}$ as $50 \%$ mineral $\mathrm{N}+25 \%$ plant compost $+25 \%$ Minia Azotene biofertilizer. Supplying the vines with $\mathrm{N}$ as $25 \%$ mineral $\mathrm{N}+37.5 \%$ plant compost + $37.5 \%$ Minia Azotene gave the lowest values. These results were true during the three seasons.

The beneficial effects of organic and biofertilization on enhancing soil fertility and the availability of most nutrients could result in enhancing growth traits (Mengel, 1984).

Enhancing cell division and the biosynthesis of carbohydrates could give another explanation.

These results are in harmony with those obtained by Madian (2010), Refaai (2011), Uwakiem (2011), El- Khafagy (2013), Shaaban (2014) and Abd El- Razek (2014) who worked in various grapevines cvs.

Table 3. Effect of organic, inorganic and biofertilization on some egetative growth characteristics of Early sweet grapevines during 2013, 2014 and 2015 seasons

\begin{tabular}{|c|c|c|c|c|c|c|c|c|c|}
\hline \multirow{2}{*}{ Treatments } & \multicolumn{3}{|c|}{ Main shoot length (cm) } & \multicolumn{3}{|c|}{ No. of leaves / shoot } & \multicolumn{3}{|c|}{ Leaf area $(\mathrm{cm})^{2}$} \\
\hline & 2013 & 2014 & 2015 & 2013 & 2014 & 2015 & 2013 & 2014 & 2015 \\
\hline $1-100 \%$ mineral N. (MN) & 88.0 & 90.0 & 91.7 & 15.0 & 15.0 & 14.0 & 105.0 & 106.1 & 105.7 \\
\hline $\begin{array}{l}2-75 \%(\mathrm{MN})+12.5 \% \\
\text { Compost }+12.5 \% \text { M.A.* }\end{array}$ & 91.9 & 93.3 & 95.0 & 17.0 & 17.0 & 16.0 & 108.0 & 110.0 & 111.0 \\
\hline $\begin{array}{l}3-50 \%(\mathrm{MN})+25 \% \text { Com- } \\
\text { post }+25 \% \text { M.A. }\end{array}$ & 95.6 & 97.0 & 97.9 & 19.0 & 19.0 & 18.0 & 110.0 & 112.2 & 113.3 \\
\hline $\begin{array}{l}4-25 \%(\mathrm{MN})+37.5 \% \\
\text { Compost }+37.5 \% \text { M.A. }\end{array}$ & 79.0 & 77.0 & 73.9 & 13.0 & 12.0 & 12.0 & 101.0 & 102.0 & 101.7 \\
\hline New L.S.D. at $5 \%$ & 2.1 & 1.9 & 2.2 & 2.0 & 2.0 & 1.9 & 1.9 & 2.0 & 2.0 \\
\hline \multirow[t]{2}{*}{ Treatments } & \multicolumn{3}{|c|}{$\begin{array}{l}\text { Wood ripening } \\
\text { coefficient }\end{array}$} & \multicolumn{3}{|c|}{ Cane thickness $(\mathrm{cm})$} & \multicolumn{3}{|c|}{$\begin{array}{c}\text { Wood pruning weight } \\
\text { (kg/ vine) }\end{array}$} \\
\hline & 2013 & 2014 & 2015 & 2013 & 2014 & 2015 & 2013 & 2014 & 2015 \\
\hline $1-100 \%$ mineral N. $(\mathrm{MN})$ & 0.70 & 0.71 & 0.71 & 0.87 & 0.88 & 0.88 & 1.95 & 1.91 & 1.93 \\
\hline $\begin{array}{l}2-75 \%(\mathrm{MN})+12.5 \% \\
\text { Compost }+12.5 \% \text { M.A.* }\end{array}$ & 0.76 & 0.77 & 0.77 & 0.95 & 0.99 & 1.01 & 2.11 & 2.13 & 2.20 \\
\hline $\begin{array}{l}3-50 \%(\mathrm{MN})+25 \% \text { Com- } \\
\text { post }+25 \% \text { M.A. }\end{array}$ & 0.83 & 0.82 & 0.84 & 1.02 & 1.06 & 1.08 & 2.22 & 2.31 & 2.33 \\
\hline $\begin{array}{l}4-25 \%(\mathrm{MN})+37.5 \% \\
\text { Compost }+37.5 \% \text { M.A. }\end{array}$ & 0.62 & 0.60 & 0.60 & 0.81 & 0.79 & 0.80 & 1.81 & 1.79 & 1.79 \\
\hline New L.S.D. at $5 \%$ & 0.05 & 0.04 & 0.05 & 0.06 & 0.06 & 0.06 & 0.09 & 0.10 & 0.10 \\
\hline
\end{tabular}

* M.A = Minia Azotene. 


\section{2- Leaf chemical composition:}

It is clear from the data Table (4

$\&$ 5) that fertilizing Early sweet grapevines with $\mathrm{N}$ as 25 to $75 \%$ mineral $\mathrm{N}$ plus 12.5 to $37.5 \%$ plant compost and Minia Azotene significantly enhanced chlorophylls a, b, total chlorophylls, total carotenoides $\mathrm{P}, \mathrm{K}$ and $\mathrm{Mg}$ in the leaves over the application of $\mathrm{N}$ via mineral source alone. The reduction on the percentage of $\mathrm{N}$ was significantly associated with reducing the percentage of mineral $\mathrm{N}$ from 100 to $25 \%$. The maximum values of leaf pigments, $\mathrm{P}, \mathrm{K}$ and $\mathrm{Mg}$ were recorded on the vine that fertilized with $\mathrm{N}$ as $25 \%$ mineral $\mathrm{N}+37.5$ $\%$ plant compost and $37.5 \%$ Minia Azotene. The highest values of $\mathrm{N}$ were recorded on the vine that received $\mathrm{N}$ completely via mineral $\mathrm{N}$ and the lowest values of leaf pigments $\mathrm{P}, \mathrm{K}$ and $\mathrm{Mg}$ were recorded on the vines that received $\mathrm{N}$ via $100 \%$ mineral $\mathrm{N}$ alone (unorganic and biofertilization). These results were true during the three seasons.

The effect of organic and biofertilizers on enhancing organic matter and reducing soil $\mathrm{pH}$ surely reflected on enhancing the availability of most nutrients. The great stimulation on root development due to application of these biostimulants surely reflected on enhancing the uptake of most nutrients (Mengel, 1984).

These results are in harmony with those obtained by Madian (2010), Refaai (2011), Uwakiem (2011) and Abd El- Razek (2014) who worked in different grapevines cvs.

\section{3- Percentage of berry setting, yield} and cluster weight:

Data in Table (5) clearly show that supplying Early sweet grapevines with $\mathrm{N}$ as 50 to $75 \%$ mineral $\mathrm{N}$ plus $12.5 \%$ to $25 \%$ plant compost and Minia Azotene significantly was effective in improving the percentage of berry setting, yield and cluster weight over the application of $\mathrm{N}$ as $100 \%$ mineral $\mathrm{N}$ or when mineral $\mathrm{N}$ was applied at $25 \%$ of the suitable $\mathrm{N}$ even with the application of organic and biofertilization significant reduction on these parameters was observed when mineral $\mathrm{N}$ was added as $25 \%$ mineral $\mathrm{N}$. Using $\mathrm{N}$ completely via inorganic $\mathrm{N}$ was significantly superior that using $\mathrm{N}$ as $25 \%$ mineral $\mathrm{N}$ plus $37.5 \%$ plant compost and Minia Azotene. Number of clusters per vine was unsignificantly affected by different $\mathrm{N}$ management in the first season of study. The best results with regard to yield were obtained with using $\mathrm{N}$ as $50 \%$ mineral $\mathrm{N}+25 \%$ plant compost $+25 \%$ Minia Azotene . Under such promised treatment yield per vine reached $12.8 \& 14.6$ and $14.9 \mathrm{~kg}$ during 2013\& 2014 and 2015 seasons, respectively. Vine fertilized with $\mathrm{N}$ completely via mineral $\mathrm{N}$ produced 11.8 \& 11.0 and $11.5 \mathrm{~kg}$ during the three seasons, respectively. These results were true during the three seasons.

The positive action of organic and biofertilization on growth, vine nutritional status, number of clusters/ vine, berry setting $\%$ and cluster weight surely reflected on improving yield.

These results are in harmony with those obtained by Madian (2010); Abd El- Kareem (2014); Alam (2014) and Abd El- Razek (2014) who worked on different grapevines cvs. 
Ahmed, et al., 2016

Table 4. Effect of organic, inorganic and biofertilization on leaf pigments and percentages of $N$ and $P$ in the leaves of Early sweet grapevines during 2013, 2014 and 2015 seasons.

\begin{tabular}{|c|c|c|c|c|c|c|c|c|c|}
\hline \multirow[t]{2}{*}{ Treatments } & \multicolumn{3}{|c|}{$\begin{array}{l}\text { Chlorophyll a } \\
\text { (mg/ } 100 \text { g F.W.) }\end{array}$} & \multicolumn{3}{|c|}{$\begin{array}{c}\text { Chlorophyll b } \\
\text { (mg/ } 100 \text { g F.W.) }\end{array}$} & \multicolumn{3}{|c|}{$\begin{array}{l}\text { Total chlorophyll } \\
\text { (mg/ } 100 \text { g F.W.) }\end{array}$} \\
\hline & 2013 & 2014 & 2015 & 2013 & 2014 & 2015 & 2013 & 2014 & 2015 \\
\hline $\begin{array}{llll}1-100 & \% & \text { mineral } & \mathrm{N} . \\
(\mathrm{MN})\end{array}$ & 6.1 & 6.2 & 6.3 & 3.3 & 3.0 & 3.0 & 9.4 & 9.2 & 9.3 \\
\hline $\begin{array}{l}2-75 \%(\mathrm{MN})+12.5 \% \\
\text { Compost }+12.5 \% \\
\text { M.A.* }\end{array}$ & 6.9 & 7.0 & 7.1 & 3.9 & 3.6 & 3.4 & 10.8 & 10.6 & 10.5 \\
\hline $\begin{array}{l}3-50 \%(\mathrm{MN})+25 \% \\
\text { Compost }+25 \% \text { M.A. }\end{array}$ & 7.5 & 7.7 & 8.0 & 4.5 & 4.1 & 4.0 & 12.0 & 11.8 & 12.0 \\
\hline $\begin{array}{l}\text { 4- } 25 \%(\mathrm{MN})+37.5 \% \\
\text { Compost }+37.5 \% \text { M.A. }\end{array}$ & 8.2 & 8.5 & 8.6 & 5.0 & 4.7 & 4.6 & 13.2 & 13.2 & 13.2 \\
\hline New L.S.D. at 5\% & 0.5 & 0.4 & 0.5 & 0.3 & 0.4 & 0.4 & 0.5 & 0.5 & 0.5 \\
\hline \multirow[t]{2}{*}{ Treatments } & \multicolumn{3}{|c|}{$\begin{array}{l}\text { Total carotenoides } \\
\text { ( mg/ } 100 \text { g F.W.) }\end{array}$} & \multicolumn{3}{|c|}{ Leaf $N \%$} & \multicolumn{3}{|c|}{ Leaf $P \%$} \\
\hline & 2013 & 2014 & 2015 & 2013 & 2014 & 2015 & 2013 & 2014 & 2015 \\
\hline $\begin{array}{llll}1-100 & \% & \text { mineral } & \mathrm{N} . \\
(\mathrm{MN})\end{array}$ & 2.9 & 3.0 & 2.9 & 1.71 & 1.75 & 1.72 & 0.15 & 0.14 & 0.15 \\
\hline $\begin{array}{l}2-75 \%(\mathrm{MN})+12.5 \% \\
\text { Compost }+12.5 \% \\
\text { M.A. }\end{array}$ & 3.3 & 3.4 & 3.3 & 1.60 & 1.64 & 1.62 & 0.18 & 0.16 & 0.18 \\
\hline $\begin{array}{l}3-50 \%(\mathrm{MN})+25 \% \\
\text { Compost }+25 \% \text { M.A. }\end{array}$ & 3.7 & 3.8 & 3.7 & 1.50 & 1.55 & 1.51 & 0.21 & 0.19 & 0.20 \\
\hline $\begin{array}{l}\text { 4- } 25 \%(\mathrm{MN})+37.5 \% \\
\text { Compost }+37.5 \% \text { M.A. }\end{array}$ & 4.0 & 4.2 & 4.0 & 1.39 & 1.44 & 1.41 & 0.23 & 0.22 & 0.23 \\
\hline New L.S.D. at 5\% & 0.3 & 0.3 & 0.3 & 0.06 & 0.05 & 0.05 & 0.02 & 0.02 & 0.02 \\
\hline
\end{tabular}

* M.A = Minia Azotene. 
Table 5. Effect of organic, inorganic and biofertilization on the percentages of $K$ and $\mathrm{Mg}$ in the leaves, berry setting \%, yield/ vine and weight of Early sweet grapevines during 2013, 2014 and 2015 seasons.

\begin{tabular}{|c|c|c|c|c|c|c|c|c|c|}
\hline \multirow{2}{*}{ Treatments } & \multicolumn{3}{|c|}{ Leaf K \% } & \multicolumn{3}{|c|}{ Leaf Mg \% } & \multicolumn{3}{|c|}{ Berry setting \% } \\
\hline & 2013 & 2014 & 2015 & 2013 & 2014 & 2015 & 2013 & 2014 & 2015 \\
\hline $\begin{array}{lrrrr}1- & 100 & \% & \text { mineral } & \mathrm{N} . \\
(\mathrm{MN}) & & & \\
\end{array}$ & 1.41 & 1.39 & 1.38 & 0.55 & 0.56 & 0.57 & 7.3 & 8.0 & 8.0 \\
\hline $\begin{array}{l}2-75 \%(\mathrm{MN})+12.5 \% \\
\text { Compost }+12.5 \% \text { M.A.* }\end{array}$ & 1.51 & 1.48 & 1.50 & 0.61 & 0.61 & 0.62 & 8.2 & 8.9 & 9.1 \\
\hline $\begin{array}{l}3-50 \%(\mathrm{MN})+25 \% \\
\text { Compost }+25 \% \text { M.A. }\end{array}$ & 1.61 & 1.59 & 1.60 & 0.66 & 0.67 & 0.67 & 9.3 & 10.0 & 10.3 \\
\hline $\begin{array}{l}4-25 \%(\mathrm{MN})+37.5 \% \\
\text { Compost }+37.5 \% \text { M.A. }\end{array}$ & 1.71 & 1.69 & 1.71 & 0.69 & 0.71 & 0.72 & 6.6 & 7.3 & 7.0 \\
\hline New L.S.D. at $5 \%$ & 0.05 & 0.05 & 0.05 & 0.04 & 0.03 & 0.04 & 0.5 & 0.5 & 0.4 \\
\hline \multirow[t]{2}{*}{ Treatments } & \multicolumn{3}{|c|}{ No. of clusters / vine } & \multicolumn{3}{|c|}{$\begin{array}{l}\text { Average cluster } \\
\text { weight (g.) }\end{array}$} & \multicolumn{3}{|c|}{ Yield/ vine (kg.) } \\
\hline & 2013 & 2014 & 2015 & 2013 & 2014 & 2015 & 2013 & 2014 & 2015 \\
\hline $\begin{array}{lllll}1- & 100 & \% & \text { mineral } & \mathrm{N} . \\
(\mathrm{MN}) & & & \end{array}$ & 23.0 & 22.0 & 23.0 & 511.0 & 501.0 & 500.0 & 11.8 & 11.0 & 11.5 \\
\hline $\begin{array}{l}2-75 \%(\mathrm{MN})+12.5 \% \\
\text { Compost }+12.5 \% \text { M.A.* }\end{array}$ & 23.0 & 24.0 & 25.0 & 523.0 & 519.0 & 520.0 & 12.0 & 12.5 & 13.0 \\
\hline $\begin{array}{l}3-50 \%(\mathrm{MN})+25 \% \\
\text { Compost }+25 \% \text { M.A. }\end{array}$ & 24.0 & 27.0 & 27.0 & 535.0 & 541.0 & 550.0 & 12.8 & 14.6 & 14.9 \\
\hline $\begin{array}{l}\text { 4- } 25 \%(\mathrm{MN})+37.5 \% \\
\text { Compost }+37.5 \% \text { M.A. }\end{array}$ & 23.0 & 20.0 & 21.0 & 481.0 & 471.0 & 461.0 & 11.1 & 9.4 & 9.7 \\
\hline New L.S.D. at $5 \%$ & NS & 2.0 & 2.0 & 11.1 & 12.0 & 12.0 & 0.2 & 0.4 & 0.5 \\
\hline
\end{tabular}

\section{* M.A = Minia Azotene}

\section{4- Shot berries \%:}

It was significantly recorded with using $\mathrm{N}$ as 50 to $75 \%$ mineral $\mathrm{N}$ besides 12.5 to $25 \%$ plant compost and Minia Azotene comparing with using $\mathrm{N}$ as $100 \%$ mineral $\mathrm{N}$ or when $\mathrm{N}$ was added as $25 \%+37.5 \%$ plant compost $+37.5 \%$ Minia Azotene biofertilizer. Using $\mathrm{N}$ as $100 \%$ mineral $\mathrm{N}$ was significantly superior than using $\mathrm{N}$ as $25 \%$ mineral $\mathrm{N}$ plus $37.5 \%$ plant compost $+37.5 \%$ Minia Azotene biofertilizer. The lowest values of shot berries $(3.7 \& 3.1$ and $2.8 \%)$ were recorded on the vines that fertilized with $\mathrm{N}$ as $50 \%$ mineral $\mathrm{N}+25 \%$ plant compost $+25 \%$ Minia Azotene biofertilizer vines fertilized with $\mathrm{N}$ as $100 \%$ mineral $\mathrm{N}$ produced $7.0 \& 6.7$ and $6.5 \%$ during $2013 \& 2014$ and 2015 seasons, respectively. These re- sults were true during the three seasons.

The great balance on $\mathrm{N}$ nutrition due to organic and biofertilization surely reflected on reducing shot berries.

These results are in harmony with those obtained by Madian (2010); Abd El Kareem (2014); Abd El- Razek (2014) and Alam (2014).

\section{5- Physical and chemical character- istics of the berries:}

It is clear from the data in Tables (6 \& 7) that supplying Early sweet grapevines with $\mathrm{N}$ as 25 to $75 \%$ mineral $\mathrm{N}$ plus $37.5 \%$ plant compost $+37.5 \%$ Minia Azotene significantly improved quality of the berries in terms of increasing berry weight and dimensions, T.S.S. \% and reducing sugars and reducing total 
acidity $\%$, nitrate and nitrite over the application of $\mathrm{N}$ via $100 \%$ mineral $\mathrm{N}$. The promotion on quality of the berries was significantly associated with reducing the percentages of mineral $\mathrm{N}$ from 100 to $25 \%$ and at the same time increasing the percentages of plant compost and Minia Azotene from 0.0 to $37.5 \%$. The best results were obtained with using $\mathrm{N}$ via $25 \%$ mineral $\mathrm{N}+37.5 \%$ plant compost + 37.5 Minia Azotene. Unfavourable effects on quality of the berries were recorded on the vines that received $\mathrm{N}$ as $100 \%$ mineral N. Similar results were announced during the three seasons.

The effect of organic and biofertilziation on advancing maturity could explain the present results.

These results are in harmony with those obtained by Madian (2010); Abd El- Kareem (2014) and Alam (2014).

6- Total counts of bacteria:

It is revealed from the data in Table (7) that fertilizing the vines with $\mathrm{N}$ as 25 to $75 \%$ mineral $\mathrm{N}$ plus $37.5 \%$ plant compost $+37.5 \%$ Minia Azotene rather than application of $\mathrm{N}$ completely via inorganic $\mathrm{N}$. The promotion on the total counts of bacteria in the soil was significantly related to the reduction in the percentages of mineral $\mathrm{N}$ and at the same time increasing the percentages of plant compost and Minia Azotene from 0.0 to $37.5 \%$. The highest values were recorded on the soil that supplied with $\mathrm{N}$ as $25 \%$ mineral $\mathrm{N}+$ $37.5 \%$ plant compost $+37.5 \%$ Minia Azotene. Fertilizing of the vines with $\mathrm{N}$ as $100 \%$ mineral $\mathrm{N}$ gave the lowest values. These results were true during the three seasons.

The beneficial effects of organic and biofertilization on activating the activity of microorganisms and organic matter could explain the present results.

These results are in harmony with those obtained by El- Khafagy (2013) and Alam (2014). 
Table 6. Effect of organic, inorganic and biofertilization on the percentage of shot berries as well as some physical and chemical characteristics of Early sweet grapevines during 2013, 2014 and 2015 seasons.

\begin{tabular}{|c|c|c|c|c|c|c|c|c|c|}
\hline \multirow[t]{2}{*}{ Treatments } & \multicolumn{3}{|c|}{$\begin{array}{c}\text { Shot berries } \\
\%\end{array}$} & \multicolumn{3}{|c|}{$\begin{array}{l}\text { Berry weight } \\
\text { (g.) }\end{array}$} & \multicolumn{3}{|c|}{$\begin{array}{l}\text { Berry longitudinal } \\
\text { (cm) }\end{array}$} \\
\hline & 2013 & 2014 & 2015 & 2013 & 2014 & 2015 & 2013 & 2014 & 2015 \\
\hline $\begin{array}{lllll}1-100 & \% & \text { mineral } & \mathrm{N} . \\
(\mathrm{MN})\end{array}$ & 7.0 & 6.7 & 6.5 & 5.00 & 5.01 & 5.00 & 2.00 & 2.00 & 1.99 \\
\hline $\begin{array}{l}2-75 \%(\mathrm{MN})+12.5 \% \\
\text { Compost }+12.5 \% \\
\text { M.A.* }\end{array}$ & 5.1 & 4.8 & 4.5 & 5.30 & 5.31 & 5.33 & 2.25 & 2.22 & 2.25 \\
\hline $\begin{array}{l}\text { 3- 50\% (MN)+25\% } \\
\text { Compost }+25 \% \text { M.A. }\end{array}$ & 3.7 & 3.1 & 2.8 & 5.62 & 5.59 & 5.64 & 2.41 & 2.39 & 2.41 \\
\hline $\begin{array}{l}2-25 \%(\mathrm{MN})+37.5 \% \\
\text { Compost }+37.5 \% \text { M.A. }\end{array}$ & 8.9 & 8.7 & 9.0 & 5.90 & 5.91 & 5.97 & 2.64 & 2.63 & 2.66 \\
\hline New L.S.D. at 5\% & 0.5 & 0.6 & 0.6 & 25 & 0.27 & 0.24 & 0.06 & 0.06 & 0.06 \\
\hline Tre & \multicolumn{3}{|c|}{$\begin{array}{l}\text { Berry equatorial } \\
(\mathbf{c m})\end{array}$} & \multicolumn{3}{|c|}{$\begin{array}{l}\text { T.S.S. } \\
\%\end{array}$} & \multicolumn{3}{|c|}{$\begin{array}{c}\text { Reducing sugars } \\
\%\end{array}$} \\
\hline & 2013 & 2014 & 2015 & 3 & 2014 & 5 & 2013 & 2014 & 2015 \\
\hline $\begin{array}{l}1-100 \% \\
(\mathrm{MN})\end{array}$ & 1.81 & 1.79 & 1.80 & 18.0 & 18.0 & 18.0 & 16.0 & 15.5 & 15.8 \\
\hline $\begin{array}{l}2-75 \%(\mathrm{MN})+12.5 \% \\
\text { Compost }+12.5 \% \\
\text { M.A.* }\end{array}$ & 1.95 & 1.94 & 1.99 & 18.5 & 19.0 & 19.0 & 16.5 & 16.0 & 16.1 \\
\hline $\begin{array}{l}3-50 \%(\mathrm{MN})+25 \% \\
\text { Compost }+25 \% \text { M.A. }\end{array}$ & 2.25 & 2.22 & 2.26 & 19.0 & 19.4 & 19.4 & 17.0 & 16.6 & 16.8 \\
\hline $\begin{array}{l}2-25 \%(\mathrm{MN})+37.5 \% \\
\text { Compost }+37.5 \% \text { M.A. }\end{array}$ & 2.50 & 2.47 & 2.52 & 19.6 & 19.8 & 20.0 & 17.5 & 17.0 & 17.2 \\
\hline New L.S.D. at 5\% & 0.06 & 0.06 & 0.06 & 0.4 & 0.4 & 0.3 & 0.3 & 0.3 & 0.4 \\
\hline
\end{tabular}

* M.A = Minia Azotene.

Table 7. Effect of organic, inorganic and biofertilization on total acidity \%, nitrate and nitrite (ppm) in the juice and total counts of bacteria in the soil of Early sweet grapevines during 2013, 2014 and 2015 seasons.

\begin{tabular}{|l|c|c|c|c|c|c|c|c|c|c|c|c|}
\hline \multirow{2}{*}{ Treatments } & \multicolumn{3}{|c|}{ Total acidity \% } & \multicolumn{3}{c|}{ Nitrate (ppm) } & \multicolumn{3}{c|}{ Nitrite (ppm) } & \multicolumn{3}{c|}{$\begin{array}{c}\text { Total counts of bacteria } \\
\text { cfu / 1 g soil }\end{array}$} \\
\cline { 2 - 15 } & $\mathbf{2 0 1 3}$ & $\mathbf{2 0 1 4}$ & $\mathbf{2 0 1 5}$ & $\mathbf{2 0 1 3}$ & $\mathbf{2 0 1 4}$ & $\mathbf{2 0 1 5}$ & $\mathbf{2 0 1 3}$ & $\mathbf{2 0 1 4}$ & $\mathbf{2 0 1 5}$ & $\mathbf{2 0 1 3}$ & $\mathbf{2 0 1 4}$ & $\mathbf{2 0 1 5}$ \\
\hline 1- 100\% mineral N. (MN) & 0.650 & 0.660 & 0.657 & 2.11 & 2.24 & 2.13 & 1.11 & 1.12 & 1.11 & $5.0^{6}$ & $5.1^{6}$ & $4.9^{6}$ \\
\hline $\begin{array}{l}\text { 2- 75\% (MN) + 12.5 \% } \\
\text { Compost + 12.5\% M.A.* }\end{array}$ & 0.610 & 0.609 & 0.603 & 1.71 & 1.51 & 1.47 & 0.96 & 0.87 & 0.85 & $5.6^{6}$ & $5.5^{6}$ & $5.5^{6}$ \\
\hline $\begin{array}{l}\text { 3- 50\% (MN)+ 25 \% } \\
\text { Compost + 25\% M.A. }\end{array}$ & 0.580 & 0.588 & 0.584 & 1.11 & 1.05 & 1.00 & 0.87 & 0.70 & 0.63 & $6.0^{6}$ & $6.0^{6}$ & $6.1^{6}$ \\
\hline $\begin{array}{l}\text { 2- 25\% (MN)+ 37.5 \% } \\
\text { Compost + 37.5 \% M.A. }\end{array}$ & 0.541 & 0.550 & 0.540 & 0.90 & 0.88 & 0.71 & 0.70 & 0.60 & 0.51 & $6.5^{6}$ & $6.6^{6}$ & $6.6^{6}$ \\
\hline New L.S.D. at 5\% & 0.027 & 0.025 & 0.024 & 0.09 & 0.10 & 0.10 & 0.11 & 0.11 & 0.11 & - & - & - \\
\hline
\end{tabular}

M.A = Minia Azotene. 


\section{Conclusion}

The best results with regard to yield of Early sweet grapevines were recorded on the vines that fertilized with $\mathrm{N}$ as $50 \%$ mineral $\mathrm{N}+25 \%$ plant compost $+25 \%$ Minia Azotene. Net return with the application of such treatment in one feddan contains 900 veins reached 4500, 5500 and 6000 LE over the check treatment during the three seasons respectively. But when we desired to promote berries quality, it is suggested to use $\mathrm{N}$ as $25 \%$ mineral $\mathrm{N}+37.5 \%$ plant compost $+37.5 \%$ Minia Azotene. In spite of the reduction on net return when such treatment was applied in one feddan the higher prices of organic grapes could compensate such loss.

\section{References}

Abd El- Kareem, A.M. (2014): The beneficial effects of biofertilization and weed control on fruiting of Superior seedless grapevines. Ph.D. Thesis Fac. of Agric. Minia Univ. Egypt.

Abd El- Razek; M.A.A. (2014): Influence of replacing a part of mineral $\mathrm{N}$ fertilizer with some organic manures enriched with Spirulina platensis algae on fruiting of Superior grapevines. M.Sc. Thesis Fac. of Agric. Minai Univ. Egypt.

Ahmed, F.F. and Morsy, M.H. (1999): A new methods for measuring leaf area in different fruit species. Minia, J. of Agric. Res., Develop. 19 pp. $97-105$.

Alam, H.M.M. (2014): Productive capacity of Superior grapevines in relation to application of some slow release fertilizers, effective microorganism and humic acid. Ph.D. Thesis Fac. of Agric. Minia Univ. Egypt.

Association of Official Agricultural Chemists (2000): Official Methods of Analysis (A.O.A.C), 12th Ed., Benjam Franklin Station, Washington D.C., U.S.A. pp. 490-510.

Balo, E.; Prilesszky, G.; Happ, L; Kaholami, M. and Vega. L. (1988): Soil improvement and the use of leaf analysis for forecasting nutrient requirements of grapes. Potash Review (Subject 9, 2nd suite. No. 61: 1-5).

Black, G.A.; Evans, D. D.; Ersminger, L. E.; White, J.L. and Dark, F.E. (1965): Methods of Soil Analysis. Amer. Soc. Agron. Inc. Bull. Medison, Wisconsin, U.S.A. pp. 891-1400.

Bouard, J. (1966): Rechockes physiologiques sur la vigne it en particulier sur laoutment des serments. Thesis sci. Nat. Bardeux, France. P. 34.

Chapman, H.D. and Pratt, P.E. (1987): Methods of Analysis for Soil, Plant and Water. Univ. California, Div. Agric. Sci. 1, 150.

Cochran, W. G. (1950): Estimation of bacterial densities by means of the "most probable Number" Biometrics 6: 105-116.

El- Khafagy, H.A. (2013): Physiological study on productivity and quality of some grape varieties under bio organic fertilization. Ph.D. Thesis community serving and Environmental studies Instit. Sadat city, Minufiya Univ.

Madian. A. M. (2010): Adjusting the best source and proportion of mineral, organic and bio nitrogen fertilizers on Red Roomy grapevines (Vitis vinifera L.). Ph.D. Thesis Fac. of Agric., Minia Univ., Egypt.

Mead, R.; Currow, R. N. and Harted, A. M. (1993): Statistics Methods in Agricultural. Biology. 2nd Ed. Chapman \& Hall, London.pp.50 70.

Mekawy, A. Y. H. (2012): Attempts for improving yield quantitively and 
qualitatively of Thompson seedless grapevines by application of some antioxidants with humic acid and farmyard manure extract. Ph.D. Thesis Fac. of Agric. Minia Univ., Egypt.

Mengel, K.E. (1984): Nutrition and Metabolism of plants. Fisher Verlage Stutgart and New York pp. 110115.

Refaai, M. M. (2011): Productive capacity of Thompson seedless grapevines in relation to some inorganic, organic and biofertilization as well as citric acid treatments. Ph.D. Thesis Fac. of Agric. Minia Univ. Egypt.

Ridnour- Lisa, A.; Sim- Julia, E.; Michael A.H.; David, A. W.; Scan, M.M.; Garry R.P. and Douglas, R.S. (2000): Aspectrophitate method for the direct and quantitation of nitric oxide, nitrite and ni- trate in cell culture media. Analytical Biochemistry, 281, 223- 229.

Shaaban, A.S.A. (2014): Effect of organic fertilization on growth and quality of Superior grapevines. Ph.D. Thesis Fac. of Agric. Cairo Univ. Egypt.

Summer, M. E. (1985): Diagnosis and Recommendation Integrated System (DRIS) as a Guide to Orchard Fertilization. Hort. Abst. 55 (8): 7502.

Uwakiem, M.Kh. (2011): Effect of some organic, bio and slow release $\mathrm{N}$ fertilizers as well as some antioxidants on vegetative growth, yield and berries quality of Thompson seedless grapevines. Ph.D. Thesis. Fac. of Agric. Minia Univ. Egypt.

Von- Wettstein, D.V.C. (1957): Clatale und der Sumbmikro Skopisne Formwechsel de platids- Experimental Cell Research, 12- 427. 
تأثير بعض معاملات التسميد العضوى والغير عضوى والحيوى على الاثمار فى كرمات العنب

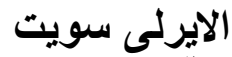

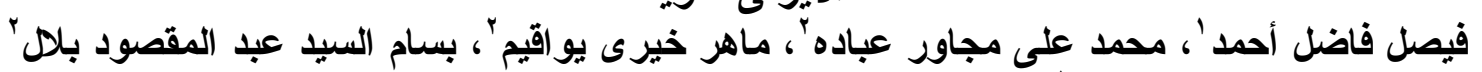

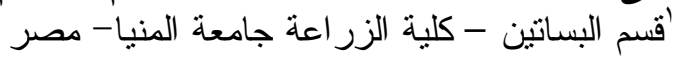





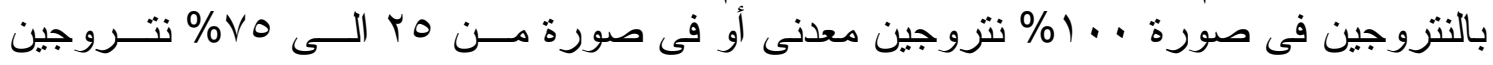



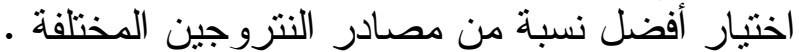



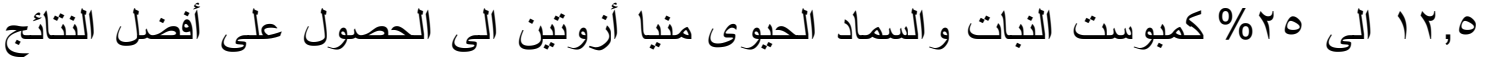

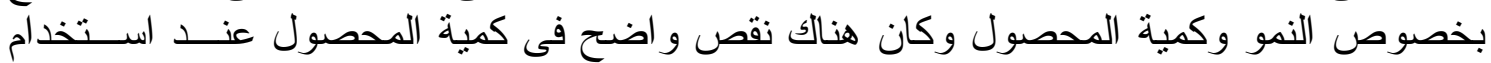

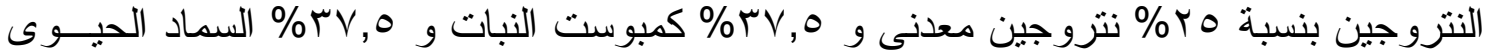
منيا أزوتين. لأجل تحسين المحصول فى كرمات العنب الايرلى سويت فانه ينصح باستخدام النتروجين

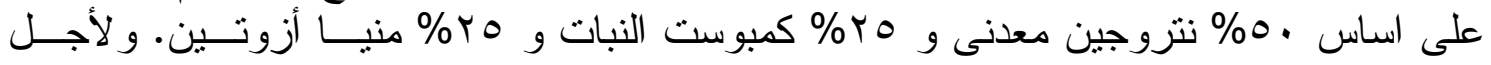

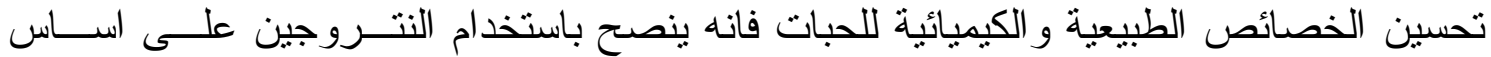

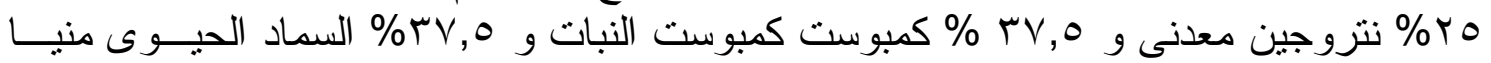
أزوتين. ألكات الدالة: السماد الغير عضوى - العضوى و الحيوى - العنب الايرلى سويت - كمبة المحصول - خصائص 